\title{
КОМПЛЕКСНЫЕ ЭЛЕКТРОРАЗВЕДОЧНЫЕ ИССЛЕДОВАНИЯ С АППАРАТУРОЙ “PHOENIX GEOPHYSICS” НА ТРУБКАХ ВЗРЫВА В ЗАПАДНОЙ ЯКУТИИ
}

\author{
Алексеев Д.А. ${ }^{1}$, Алексеева Е.С. ${ }^{1}$, Манаков А.В. ${ }^{2}$, Матросов B.A. ${ }^{2}$, Яковлев А.Г. ${ }^{1}$, \\ 1 - ООО «Северо-3аnad», 2 - ЯНИГП ЦНИГРИ АК «АЛРОСА»
}

В 2005 г. ООО “Северо-Запад” на полигоне в Алакит-Мархинском кимберлитовом поле (Западная Якутия) были выполнены площадные аудиомагнитотеллурические зондирования, а также площадные электроразведочные исследования с конроллируемым источником поля. Исследования носили статус опытно-методических работ и были направлены на оценку возможностей применяемых методов при картировании трубок взрыва.

Электроразведочные исследования выполнялись в варианте аудиомагнитотеллурического зондирования (АМТЗ), а также в варианте с искусственным возбуждением поля (CSEM Controlled Source Electromagnetics). Последний вариант предполагал возбуждение электрического поля в изучаемой среде с помощью заземленных питающих (генераторных) линий. Регистрация поля в этом случае проводилась с применением стандартной расстановки АМТЗ.

Результаты интерпретации полученных данных позволяют говорить о проявленности кимберлитового тела “Файнштейновская” в магнитотеллурических передаточных операторах (импедансе и типпере), а также в аномалии поля вызванной поляризации. Получена геоэлектрическая модель геологического разреза исследуемой площади, в которой выражены область кимберлитового тела, а также региональные геолого-гидрогеологические особенности (трапповый, терригенный и карбонатный комплексы, а также область обводненности разреза).

Уникальной стороной проведенных исследований является выделение эффектов ВП в сигналах искусственного источника поля, зарегистрированных с помощью аппаратуры Phoenix. Это первый подобный опыт и наиболее интересный из полученных результатов связан именно с применением технологии вызванной поляризации. 